\title{
Severe hypernatremia and hyperchloremia in an elderly patient with lgG-kappa-type multiple myeloma
}

This article was published in the following Dove Press journal:

Journal of Blood Medicine

13 May 2013

Number of times this article has been viewed

\section{Shinsaku Imashuku \\ Naoko Kudo \\ Kagekatsu Kubo}

Division of Hematology, Takasagoseibu Hospital, Takasago, Japan
Correspondence: Shinsaku Imashuku Division of Hematology, Takasago-seibu Hospital, I-I0-4I Nakasuji,

Takasago, Japan 676-0812

Tel $+8 I 794470100$

Fax +81794470180

Email shinim95@mbox.kyoto-inet.or.jp
Abstract: A 77-year-old male was admitted to hospital after suffering a pelvic bone fracture in a road traffic accident and was incidentally found to have IgG-kappa-type multiple myeloma with hypercalcemia. The patient was also noted to be hypokalemic and had low $\mathrm{HCO}_{3}^{-}$, with possible damage to the distal tubules in the kidneys. When the treatment was begun with bortezomib/ dexamethasone/elcatonin and sodium bicarbonate $\left(\mathrm{NaHCO}_{3}\right)$ in normal saline (equivalent to a daily sodium dose of 200 millimoles per liter $[\mathrm{mmol} / \mathrm{L}]$ ), the patient was in a state of poor oral fluid intake. The patient developed hypernatremia and hyperchloremia, with a peak serum sodium and chloride levels of $183 \mathrm{mmol} / \mathrm{L}$ and $153 \mathrm{mmol} / \mathrm{L}$, respectively, at the sixth day after the start of treatment. Following the switch of the intravenous infusions from normal saline to soldem 1 and soldem 3 solutions, these high-electrolyte levels gradually returned to normal over the next 7 days. Although the patient showed disturbed consciousness (Japan Coma Scale = JCS-I-3) during the period of electrolyte abnormality, he eventually fully recovered without sequelae. In this patient, we successfully managed the severe hypernatremia/hyperchloremia, caused by the combined effects of intravenous saline burden in a state of poor oral fluid intake, during the treatment for IgG-kappa type multiple myeloma.

Keywords: hypernatremia, hyperchloremia, multiple myeloma, IgG-kappa, metabolic acidosis, renal tubular damage

\section{Introduction}

Hypernatremia (serum sodium concentration $>146$ millimoles per liter $[\mathrm{mmol} / \mathrm{L}]$ ) is a common electrolyte disorder that can occur in very young or elderly patients..$^{1,2}$ Severe hypernatremia is defined as a serum sodium concentration $>160 \mathrm{mmol} / \mathrm{L} .^{3}$ Hypernatremia may be caused by simple excess of sodium, often resulting from dehydration, due to excessive water loss or the ingestion of hypertonic fluids. Large losses of low-salt body fluids can occur during episodes of diarrhea or after the administration of diuretics or may result from renal tubular damage in patients with nephrogenic diabetes insipidus. ${ }^{1}$

Hypernatremia may occur with the use of certain drugs, such as lithium and valproate, which may lead to renal impairment. ${ }^{4,5}$ Hypernatremia can also occur in patients treated with excess sodium bicarbonate $\left(\mathrm{NaHCO}_{3}\right)$ to correct metabolic acidosis, which may increase the concentration of sodium in the serum. ${ }^{6}$ Particular attention must be paid to hypernatremic episodes occurring in elderly patients, which are usually caused by high-salt loads due to poor oral fluid intake. Multiple myeloma is one of the common hematological diseases in elderly patients. In the past, reports are available on IgG-kappa-type multiple myeloma and proximal renal tubular acidosis 
(Fanconi syndrome), ${ }^{6-15}$ but the occurrence of hypernatremia in such cases has rarely been described. ${ }^{16}$

Here, we report the case of an elderly patient presenting with multiple myeloma and underlying renal tubular damage, who developed extreme hypernatremia (peak serum sodium concentration, $183 \mathrm{mmol} / \mathrm{L}$ ) and hyperchloremia (peak serum chloride concentration, $153 \mathrm{mmol} / \mathrm{L}$ ) after intravenous treatment with bortezomib/dexamethasone/elcatonin and $\mathrm{NaHCO}_{3}$ in normal saline.

\section{Case report}

A 77-year-old man (height, $170 \mathrm{~cm}$; body weight, $55 \mathrm{~kg}$; blood pressure, 172/66 mmHg; and heart rate, 84 beats per minute) was transferred to our care after being injured in a road traffic accident. On admission, he had an Eastern Cooperative Oncology Group performance score of 4 . His medical history prior to admission was not significant. A computed tomography scan revealed a fracture of the left pelvic bone (Figure 1). The laboratory findings were: white blood count, $5600 / \mu \mathrm{L}$; hemoglobin, $9.9 \mathrm{~g} / \mathrm{dL}$; platelet count, $142,000 / \mu \mathrm{L}$; aspartate transaminase, 42 (normal range; 13-37) units/L; alanine aminotransferase, 21 (8-45) units/L; lactate dehydrogenase, 402
(122-228) units/L; ammonium, $61(<100) \mu \mathrm{g} / \mathrm{dL}$; total protein, 9.1 (6.7-8.3) g/dL; albumin, 3.1 (4.1-5.2) g/dL; blood urea nitrogen, 18.1 (7.8-18.9) $\mathrm{mg} / \mathrm{dL}$; creatinine, 1.73 (0.64-1.11) mg/dL; uric acid, 9.3 (3.0-7.0) mg/dL; estimated glomerular filtration rate, 41.5 (>90) $\mathrm{mL} / \mathrm{min} / \mathrm{L} ; \mathrm{Ca}, 11.9$ (8.7-10.3) $\mathrm{mg} / \mathrm{dL}$; inorganic phosphate (IP), 2.6 (2.9-4.9) $\mathrm{mg} / \mathrm{dL}$; Na, 140 (138-146) mmol/L; K, 2.8 (3.6-5.1) $\mathrm{mmol} / \mathrm{L} ; \mathrm{Cl}, 102$ (99-108) mmol/L; and serum beta 2-microglobulin, 3.1 (0.9-1.9) mg/L.

Urinalysis revealed a $\mathrm{pH}$ of 5.0 with occult blood (2+) and protein $(2+)$ but glucose $(-)$. Because the patient showed high levels of total protein in the serum, we considered a differential diagnosis of multiple myeloma. Further tests revealed serum IgG levels of 4389 (870-1700) $\mathrm{mg} / \mathrm{dL}$, with IgG-kappa-type $\mathrm{M}$ protein. Bence-Jones protein was also detected in the urine. The bone marrow comprised $60 \%$ myeloma cells. Based on these findings, the patient was diagnosed with multiple myeloma (Durie-Salmon stage 2A). Clinically, the patient showed the complete range of multiple myeloma symptoms (hypercalcemia, renal dysfunction, anemia, and bone disease, such as osteolytic pelvic bones and ribs), which had been unrecognized until hospital admission.

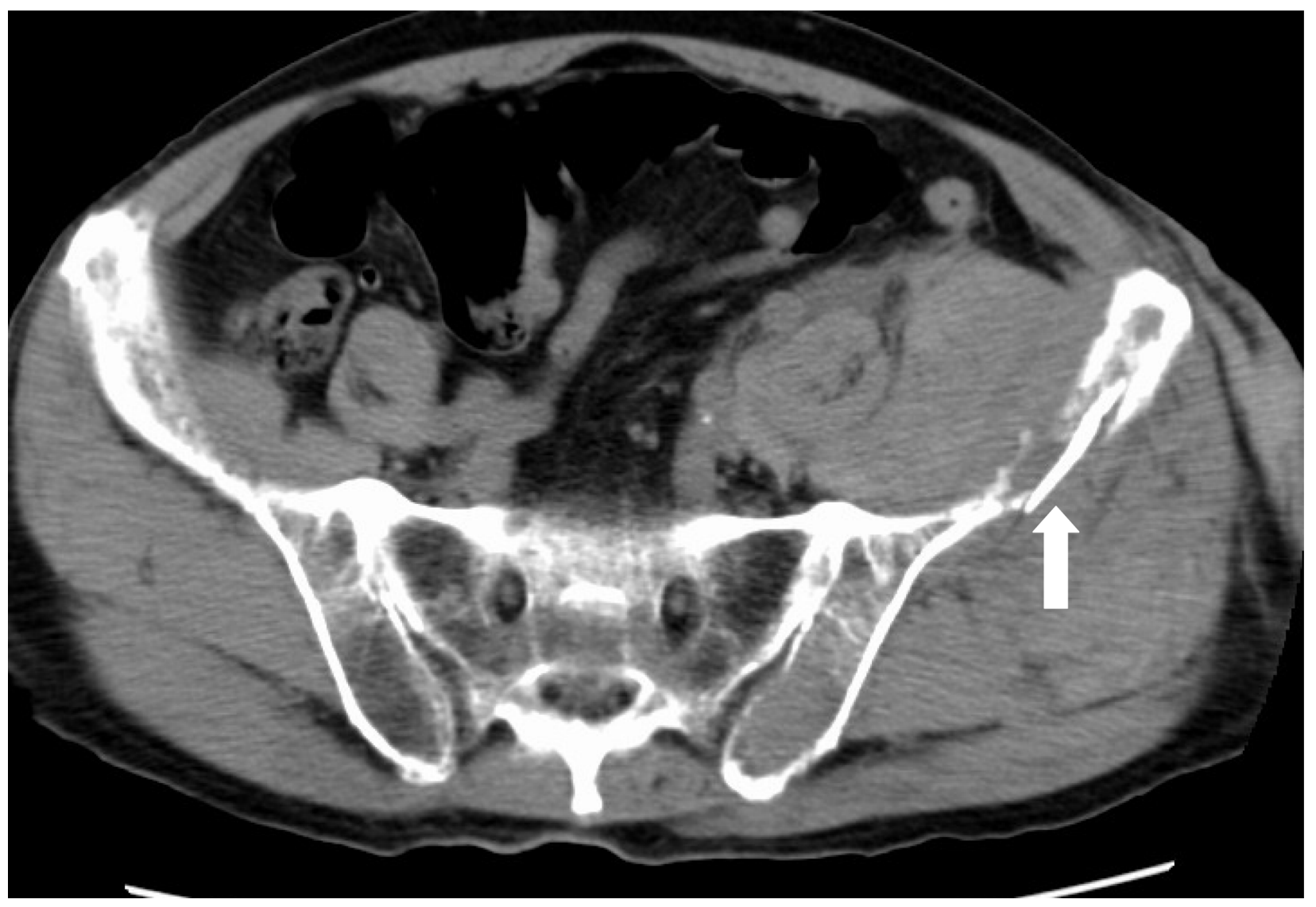

Figure I CT scan showing a fracture of the left ilium (arrow), which caused a large hematoma. 
During the first week after admission, the patient was able to communicate but was somehow in a state of a mild disturbance of consciousness (Japan Coma Scale; JCS-I-2; disoriented) and had difficulty imbibing oral fluids; thus, he was hydrated with $1000-1500 \mathrm{~mL}$ of peripheral parenteral nutrition solution (soldem 3: sodium $[\mathrm{Na}]$ concentration, $35 \mathrm{mmol} / \mathrm{L}$; chloride [Cl] concentration, $35 \mathrm{mmol} / \mathrm{L}$ ).

After the diagnosis of multiple myeloma with hypercalcemia, specific treatment was instigated, according to the following protocol (Figure 2): intravenous normal saline (Na, $154 \mathrm{mmol} / \mathrm{L} ; \mathrm{Cl}, 154 \mathrm{mmol} / \mathrm{L} ; 500 \mathrm{~mL} \times 2 /$ day; daily), dexamethasone ( $8 \mathrm{mg}$ per day $\times 2$ consecutive days), $\mathrm{NaHCO}_{3}$ ( $80 \mathrm{mmol} / \mathrm{L}$ per day; daily), bortezomib $\left(1.3 \mathrm{mg} / \mathrm{m}^{2}\right.$ per dose, weekly), elcatonin (40 units per day for 5 consecutive days), and zoledronic acid hydrate (4 mg per dose, monthly). All drugs were intravenously administered in normal saline (N/S); thus, the patient received $200 \mathrm{mmol} / \mathrm{L}$ of sodium per 24 hours over a period of 6 days.

As shown in Figure 2, the patient experienced a gradual increase in serum sodium and chloride levels, which peaked at $183 \mathrm{mmol} / \mathrm{L}$ and $153 \mathrm{mmol} / \mathrm{L}$, respectively.

At this point, his consciousness deteriorated further (JCS-I-3; confused). The patient was then switched to an intravenous infusion $(1500 \mathrm{~mL})$ of soldem $1(\mathrm{Na}, 90 \mathrm{mmol} / \mathrm{L}$; $\mathrm{Cl}, 70 \mathrm{mmol} / \mathrm{L})$, soldem 3 , and potassium chloride $(\mathrm{KCl})$ in $5 \%$ glucose, which helped gradually resolve the hypernatremia/hyperchloremia over the next 7 days, but the patient continued to have difficulty in swallowing and a

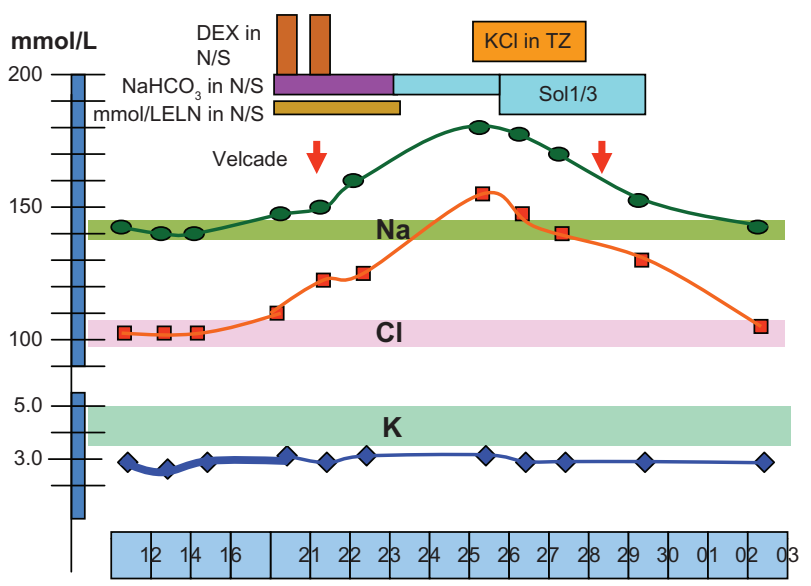

Figure 2 Clinical course of electrolyte disturbances (hypokalemia and hyper natremia/hyperchloremia) in association with treatment for multiple myeloma.

Notes: The numbers in the blue boxes running along the bottom of Figure 2 represent dates between November 12-16 and November 21-30, 2012, and December I-3, 2012. The horizontal colored bars represent the normal ranges for sodium (green), chloride (pink), and potassium (pale blue).

Abbreviations: DEX, dexamethasone (8 mg per dose); ELN, elcatonin; $\mathrm{KCl}$, potassium chloride; $\mathrm{Na}$, sodium; $\mathrm{NaHCO}_{3}$, sodium bicarbonate; $\mathrm{N} / \mathrm{S}$, normal saline; TZ, 5\% glucose; Sol I/3, soldem I and soldem 3 infusion fluids; Velcade, bortezomib (1.5 mg per dose). low oral fluid intake. The patient's disturbed consciousness persisted for almost a month, then the situation improved significantly thereafter. During the entire period of hypernatremia/hyperchloremia, low serum potassium and IP levels also persisted. The former was associated with the excretion of high levels of potassium $(38 \mathrm{mmol} / \mathrm{L}$; normal levels, $<20 \mathrm{mmol} / \mathrm{L}$ ), although IP excretion was normal (1.14 grams per day; normal range, 0.5 grams-2.0 grams per day). There was no evidence of glucosuria, hypouricemia, or generalized aminoaciduria. While examining other factors that might contribute to the electrolyte disorders in this patient, we observed that, although the levels of adrenocorticotropic hormone (19.9 pg/mL), plasma renin ( $2.4 \mathrm{ng} / \mathrm{mL}$ per hour), and aldosterone $(56 \mathrm{pg} / \mathrm{mL})$ were all within the normal range, his serum cortisol levels $(22.4$ $\mu \mathrm{g} / \mathrm{dL})$ were slightly elevated. Arterial blood gas analysis, which was performed not in the critical period, but in the convalescent phase of the disease, revealed the following: $\mathrm{pH}, 7.481 ; \mathrm{PaO}_{2}, 84.0 \mathrm{mmHg} ; \mathrm{PaCO}_{2}, 28.2 \mathrm{mmHg}$; $\mathrm{HCO}_{3}^{-}$, 20.8 (normal; 23-31) mmol/L base excess, $-1.0 \mathrm{mmol} / \mathrm{L}$; and anion gap, 8.9 (normal; <12) mmol/L. These data were suggestive of metabolic acidosis. However, the urine anion gap was $48 \mathrm{mmol} / \mathrm{L}$. We later confirmed that the patient's low-serum potassium and plasma $\mathrm{HCO}_{3}^{-}$levels eventually normalized after a month. Taken together, these data suggested that the patient was probably suffering from distal renal tubular damage ${ }^{17}$ during the period of severe hypernatremia/hyperchloremia. Thereafter, the patient has fully recovered with no further disturbances of consciousness and with normal oral fluid intake, and continues to receive treatment for multiple myeloma.

\section{Discussion}

Severe hypernatremia (defined as a serum sodium concentration $>160 \mathrm{mmol} / \mathrm{L})^{3}$ has been described in various case reports, as high as a serum $\mathrm{Na}$ concentration of $196 \mathrm{mmol} / \mathrm{L}, 201 \mathrm{mmol} / \mathrm{L}, 202 \mathrm{mmol} / \mathrm{L}$, or $211 \mathrm{mmol} / \mathrm{L} .3,5,18,19$ In addition, in a reported case of fatal ingestion of sodium hypochlorite bleach, the patient showed hypernatremia (serum $\mathrm{Na}, 169 \mathrm{mmol} / \mathrm{L})$ and hyperchloremia $(\mathrm{Cl}, 143 \mathrm{mmol} / \mathrm{L})$ in association with metabolic acidosis, ${ }^{20}$ and a patient with acute salt poisoning, due to an overdose of sodium chloride, showed a Na load of $400 \mathrm{mmol} / \mathrm{L}$ over 12 hours. ${ }^{21}$ Here, we report a case of severe hypernatremia $(\mathrm{Na}, 183 \mathrm{mmol} / \mathrm{L})$ in a patient with multiple myeloma. To date, however, few cases of hypernatremia in association with multiple myeloma have been described. ${ }^{16}$ In the present case, hypernatremia occurred after the patient was hydrated intravenously mainly with N/S 
as well as all necessary drugs (bortezomib, dexamethasone, elcatonin, and $\mathrm{NaHCO}_{3}$ ) were given in $\mathrm{N} / \mathrm{S}$, as he was unable to take fluids orally. Besides the high-saline burden, $\mathrm{NaHCO}_{3}{ }^{16}$ and dexamethasone administration might have accelerated the hypernatremia. In calculation, he received a salt load of $200 \mathrm{mmol} / \mathrm{L}$ over 24 hours, which was nearly comparable to one-fourth of the dose in a fatal case of household bleach ingestion reported by Ross et al. ${ }^{20}$ The peak serum concentrations of sodium and chloride in the current patient reached $183 \mathrm{mmol} / \mathrm{L}$ and $153 \mathrm{mmol} / \mathrm{L}$, respectively. Although the patient suffered some mild disturbances of consciousness, he made a full recovery within approximately 1 month, with no residual adverse effects.

In our case, the cause of the hypernatremia/hyperchloremia was likely to be linked to the renal tubular damage due to multiple myeloma, as the laboratory data showed a normal blood anion gap and a high urine anion gap, both of which are indicative of hyperchloremic acidosis (base excess $<-2 \mathrm{mmol} / \mathrm{L}$; anion gap $<17 \mathrm{mmol} / \mathrm{L}){ }^{22}$ In general, decreases in plasma $\mathrm{HCO}_{3}^{-}$levels are associated with hyperchloremic acidosis and lactic acidosis. Both type 1 (distal) and type 2 (proximal) renal tubular damage have been reported in patients with multiple myeloma and other related diseases. ${ }^{6-15}$ In particular, distal renal tubular acidosis is characterized by hyperchloremic metabolic acidosis $^{23}$ and hypokalemia. ${ }^{24}$ On the other hand, Sakaue et al and Uchida et al described IgG-kappa-induced proximal renal tubular acidosis, as observed in Fanconi syndrome, in patients with IgG-kappa type myeloma. ${ }^{14,15}$ Although the patient in the present study showed persistently low levels of $\mathrm{HCO}_{3}^{-}$, hypokalemia, and hypophosphatasia, he did not show evidence of glucosuria or generalized aminoaciduria, indicating that he did not have Fanconi syndrome. Therefore, we concluded that the extreme hypernatremia/ hyperchloremia was due to a combination of excess saline and $\mathrm{NaHCO}_{3}$, dexamethasone administration in association with poor oral fluid intake, on top of the distal renal tubular damage caused by multiple myeloma.

Considering the rarity of hypernatremia regardless of renal tubular damage in patients with multiple myeloma, it remains unclear how much myeloma-associated renal damage played a role in causing severe hypernatremia in this patient.

The outcome of myeloma-related renal tubular damage is not clear. Minemura et $\mathrm{al}^{8}$ reported that renal tubular acidosis was not improved by treating the myeloma with chemotherapy agents; indeed, in their case, the patient died from an exacerbation of the disease. On the other hand, Uchida et $\mathrm{l}^{15}$ reported a case in which renal tubular acidosis was corrected after chemotherapy for multiple myeloma, and Sakaue et $\mathrm{al}^{14}$ reported that serum IgG levels and urine sugar levels decreased, and serum potassium levels returned to normal, in a patient receiving chemotherapy for multiple myeloma. In the current case, the patient recovered from the electrolyte disturbances and acidosis within a month, responding to the myeloma therapy. The improvement in the electrolyte imbalance was associated with a return to normal levels of consciousness.

\section{Conclusion}

In summary, there appears to be an increased risk of hypernatremia in elderly patients with renal tubular damage associated with multiple myeloma; therefore, clinicians must exercise caution and not prescribe excess salt, particularly in elderly patients who have difficulty taking oral fluids.

\section{Consent}

Written, informed consent to publish this case report was obtained from the caregiver of the patient involved.

\section{Author contributions}

SI, NK, and KK contributed equally to this work; SI, NK, and KK managed the patient; KK performed bone marrow studies; all authors prepared the manuscript; all authors read and approved the final manuscript.

\section{Disclosure}

The authors report no conflicts of interest in this work.

\section{References}

1. Conley SB. Hypernatremia. Pediatr Clin North Am. 1990;37(2): 365-372.

2. Snyder NA, Feigal DW, Arieff AI. Hypernatremia in elderly patients. A heterogeneous, morbid, and iatrogenic entity. Ann Intern Med. 1987; 107(3):309-319.

3. Jeffery J, Ayling RM, McGonigle RJ. Successful rescue of severe hypernatraemia $(196 \mathrm{mmol} / \mathrm{L})$ by treatment with hypotonic fluid. Ann Clin Biochem. 2007;44(Pt 5):491-494.

4. Sze L, Ulrich B, Brändle M. Severe hypernatraemia due to nephrogenic diabetes insipidus - a life-threatening side effect of chronic lithium therapy. Exp Clin Endocrinol Diabetes. 2006;114(10):596-598.

5. Anand G, Ali T, Craze J. An unusual case of extreme natraemia. BMJ Case Rep. 2009;pii:bcr03.2009.1697.

6. Kobayashi T, Muto S, Nemoto J, et al. Fanconi’s syndrome and distal (type 1) renal tubular acidosis in a patient with primary Sjögren's syndrome with monoclonal gammopathy of undetermined significance. Clin Nephrol. 2006;65(6):427-432.

7. Lazar GS, Feinstein DI. Distal renal tubular acidosis in multiple myeloma. Arch Intern Med. 1981;141(5):655-656.

8. Minemura $\mathrm{K}$, Ichikawa $\mathrm{K}$, Itoh $\mathrm{N}$, et al. IgA-kappa type multiple myeloma affecting proximal and distal renal tubules. Intern Med. 2001; 40(9):931-935

9. Doi K, Teramoto S, Hosoi T, et al. Renal tubular acidosis type II secondary to gamma-light chain excretion in an elderly patient with multiple myeloma. Nihon Ronen Igakkai Zasshi. 1998;35(6):477-481. Japanese [with English abstract]. 
10. Schillinger F, Hopfner C, Montagnac R, Milcent T. IgG kappa myeloma with Fanconi's syndrome and crystalline inclusions. Immunohistochemical and ultrastructural study. Presse Med. 1993;22(14):675-679. French [with English abstract].

11. Decourt C, Bridoux F, Touchard G, Cogné M. A monoclonal V kappa 1 light chain responsible for incomplete proximal tubulopathy. Am J Kidney Dis. 2003;41(2):497-504.

12. Bridoux F, Sirac C, Hugue V, et al. Fanconi's syndrome induced by a monoclonal Vkappa3 light chain in Waldenstrom's macroglobulinemia. Am J Kidney Dis. 2005;45(4):749-757.

13. Messiaen T, Deret S, Mougenot B, et al. Adult Fanconi syndrome secondary to light chain gammopathy. Clinicopathologic heterogeneity and unusual features in 11 patients. Medicine (Baltimore). 2000; 79(3):135-154.

14. Sakaue S, Nakata K, Nagata H, Yamaguchi J. A case of IgG-kappa type multiple myeloma complicated by Fanconi syndrome. Rinsho Ketsueki. 1994;35(8):786-791. Japanese [with English abstract].

15. Uchida S, Matsuda O, Yokota T, et al. Adult Fanconi syndrome secondary to kappa-light chain myeloma: improvement of tubular functions after treatment for myeloma. Nephron. 1990;55(3):332-335.

16. Hoorn EJ, Zietse R. Combined renal tubular acidosis and diabetes insipidus in hematological disease. Nat Clin Pract Nephrol. 2007; 3(3):171-175.

17. Vaidya G, Ganeshpure S. Sjogren's syndrome with distal renal tubular acidosis presenting as hypokalaemic paralysis. BMJ Case Rep. 2012;pii:bcr2012007568.
18. Chisti MJ, Pietroni MA, Alom MS, Smith JH. Use of only oral rehydration salt solution for successful management of a young infant with serum sodium of $201 \mathrm{mmol} / \mathrm{L}$ in an urban diarrhoeal diseases hospital, Bangladesh. J Health Popul Nutr. 2012;30(3):371-376.

19. Paut O, André N, Fabre P, et al. The management of extreme hypernatraemia secondary to salt poisoning in an infant. Paediatr Anaesth. 1999;9(2):171-174.

20. Ross MP, Spiller HA. Fatal ingestion of sodium hypochlorite bleach with associated hypernatremia and hyperchloremic metabolic acidosis Vet Hum Toxicol. 1999;41(2):82-86.

21. el-Dahr S, Gomez RA, Campbell FG, Chevalier RL. Rapid correction of acute salt poisoning by peritoneal dialysis. Pediatr Nephrol. 1987; 1(4):602-604.

22. Story DA, Morimatsu H, Bellomo R. Hyperchloremic acidosis in the critically ill: one of the strong-ion acidoses? Anesth Analg. 2006; 103(1):144-148.

23. Bouzidi H, Daudon M, Najjar MF. Primary distal renal tubular acidosis. Ann Biol Clin (Paris). 2009;67(2):135-140. French [with English abstract].

24. Comer DM, Droogan AG, Young IS, Maxwell AP. Hypokalaemic paralysis precipitated by distal renal tubular acidosis secondary to Sjögren's syndrome. Ann Clin Biochem. 2008;45(Pt 2):221-225.

\section{Publish your work in this journal}

The Journal of Blood Medicine is an international, peer-reviewed, open access, online journal publishing laboratory, experimental and clinical aspects of all topics pertaining to blood based medicine including but not limited to: Transfusion Medicine; Blood collection, Donor issues, Transmittable diseases, and Blood banking logistics; Immunohematology; Artificial and alternative

\section{Dovepress}

blood based therapeutics; Hematology; Biotechnology/nanotechnology of blood related medicine; Legal aspects of blood medicine; Historical perspectives. The manuscript management system is completely online and includes a very quick and fair peer-review system. Visit http://www.dovepress.com/ testimonials.php to read real quotes from published authors. 